
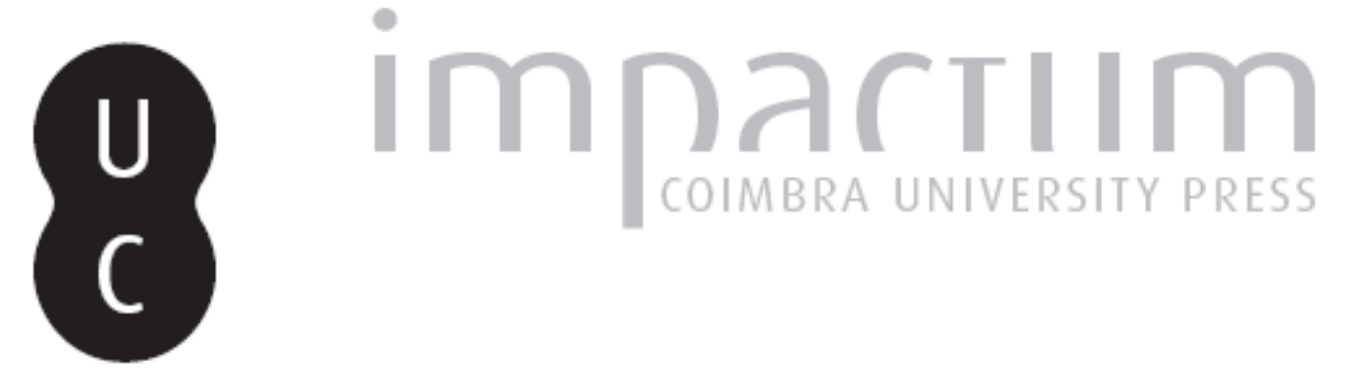

\title{
Review of Cooksey T. L., Plato's Symposium: A Reader Guide
}

\section{Autor(es): $\quad$ Candiotto, Laura}

Publicado por: Imprensa da Universidade de Coimbra

URL persistente:

URI:http://hdl.handle.net/10316.2/42177

DOI:

DOI:https://doi.org/10.14195/2183-4105_12_11

Accessed : $\quad$ 26-Apr-2023 16:13:12

A navegação consulta e descarregamento dos títulos inseridos nas Bibliotecas Digitais UC Digitalis, UC Pombalina e UC Impactum, pressupõem a aceitação plena e sem reservas dos Termos e Condições de Uso destas Bibliotecas Digitais, disponíveis em https://digitalis.uc.pt/pt-pt/termos.

Conforme exposto nos referidos Termos e Condições de Uso, o descarregamento de títulos de acesso restrito requer uma licença válida de autorização devendo o utilizador aceder ao(s) documento(s) a partir de um endereço de IP da instituição detentora da supramencionada licença.

Ao utilizador é apenas permitido o descarregamento para uso pessoal, pelo que o emprego do(s) título(s) descarregado(s) para outro fim, designadamente comercial, carece de autorização do respetivo autor ou editor da obra.

Na medida em que todas as obras da UC Digitalis se encontram protegidas pelo Código do Direito de Autor e Direitos Conexos e demais legislação aplicável, toda a cópia, parcial ou total, deste documento, nos casos em que é legalmente admitida, deverá conter ou fazer-se acompanhar por este aviso. 
O

Established 1989

$\bigcirc$

$\vdash$

$<$

$\dashv$

ㅇ

-
$Z$
0
-
1
$Z$
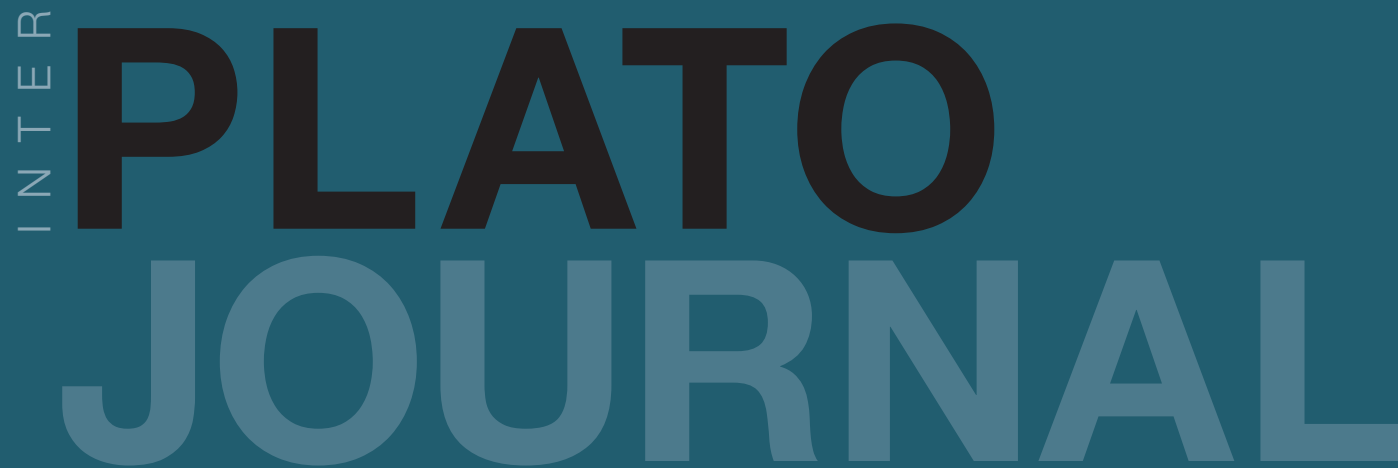

Société Platonicienne Internationale

Associazione Internazionale dei Platonisti

Sociedad Internacional de Platonistas

Internationale

Platon-Gesellschaft 
Review of Thomas L. Cooksey, Plato's Symposium: A Reader's Guide, Continuum, London-New York. 2010.

The book consists of four chapters (1.Context; 2 . Overview of Themes; 3 . Reading the Text; 4. Reception and Influence) that offer the reader guidance in reading Plato's Symposium. Secondary literature is mostly in English. The line of interpretation may be defined as partly literary and partly thematic - being aware of the philosophical significance of the adopted style. The literary part contains a detailed description of the characters and the frame story; the thematic part comprises: frequent comparisons and parallelisms, philosophical thoughts from another time (up to the present) and other disciplines, particularly from a psychological perspective. Even though the text might have a didactic approach ${ }^{1}$ it provides some interesting hermeneutic interpretations that I would like to underline:

1) The symposium as a literary device: it allows Plato to explore the power and nature of the erotic, and how it relates to issues of ethics, epistemology, and ontology. Moreover, it pretends to be the very representation of the nature of the philosopher. Cooksey reads the dialogue as a unit, taking a steep slope - though he does not really leave behind the slope already overcome- from the first encomia to those of Diotima and Alcibiades, which are interpreted simultaneously ${ }^{2}$. Plato conceived the Symposium as a tragic trilogy followed by a "satyr- play". The first installment of Plato's trilogy can be characterized as "Love and the individual", joining the encomia of Phaedrus and Pausanias into a contrasting pair that brings them together as dialectical complements to each other. The second installment might be called "Love and nature". Here Eryximachus and Aristophanes form a dialectical complement. The third and culminating installment of the trilogy might be called "Love in itself". Agathon and Socrates/Diotima form the dialectical complement. The "satyr play" of Alcibiades takes up the various themes developed during the course of the first three installments, translating them from the realm of the heroic and mythic into the living realm of humans.

In addition to this dramatic structure, Cooksey individualizes the larger narrative contexts represented by the roles played by Aristodemus, Apollodorus, and ultimately Plato.

According to Cooksey (a view developed by Despand 1985, by Chateau 2005, by Ortega y Gasset 1957 and by Bakhtin 1981) this fact makes the Symposium a unitary dialogue, where thanks to the philosophy tragedy and comedy are restored to wholeness.

Personally I think that this kind of interpretation is fundamental to contextualize

\footnotetext{
${ }^{1}$ See the "discussion questions" proposed at the end of chapter 3, pp. 131-132.

${ }^{2}$ See paragraph 5.

PLATO, The electronic Journal of the International Plato Society, 12, 2012.

http://gramata.univ-paris1.fr/Plato/article114.html,

(C) All rights of reproduction of any form reserved.
} 
the philosophical doctrines. On the one hand, to gather the intentions and aims of platonic writing, and on the other, to understand the philosophical meaning emerging from the text. There is not a dichotomy between style and content or an asymmetrical advantage of the content over the style: these two parts work together in order to explore the concept that arises from the text. This awareness is to be found in many of the studies carried out on Plato over recent years. Cooksey's work constitutes a worthy part of this hermeneutic vein. At this point, a most important observation is that, apart from what has been said about the one-on-one dialectical relationships of the trilogy, Cooksey conceives the "dialectic" in what I would call a contemporaneous way: the dialectic is not the contrast or the overcoming of a thesis by contradiction (as it was for Socrates and Hegel), but the participants' desire to achieve a mutual agreement on a dialogical composition, which is typical of a 'democratic' and contemporaneous conception. I personally do not agree with the universalization of the 'common research' as an agreement among the participants of the Socratic dialogue, even being one of its most characteristics aspects. This definition underlines a 'democratic' conception of knowledge. I believe to be it an anachronism and a simplification of ancient Greek culture. Unfortunately all too often, I observe in this contemporary reading the limits of a text that is proposed as a reading guide instead of as a theoretical comparison. It is, however, true that this can bring students closer to the Greek world. Yet it should express that this inclination for contemporaneity is just a suggestion, not an addition to what has been written by Plato.

Nevertheless, from a theoretical point of view an update of the dialogue's form is very interesting., since the 'Socratic dialogue' is applied in several educational and formative contexts as an implementation. Moreover, these topics can't be adequately explained in an introductory book about the Symposium. Otherwise, there is a risk that the reader (in particular if inexperienced) would not be able to understand in what way it is indeed present in the platonic work and to what extent it constitutes an evolution from its ancient example.

2) A positive interpretation of Eryximachus: Cooksey points out an important step forward on the moral relativism of Phaedrus and Pausanias: "The transition to a moral "physics", grounded in a relationship with nature, ultimately pointing to a moral metaphysics, grounded in transcendent forms". Eryximachus' encomium prepares the audience for the speech of Socrates/Diotima and the transcendental philosophy of Plato. After having emphasized the common points with Empedocles and Hippocrates, Cooksey underlines the resemblance with Plato's theory of the tripartition of the human soul ${ }^{3}$ and the conception of health as the harmony between the parts.

3) Love is neither mortal nor immortal ${ }^{4}$ : Cooksey underlines the fact that, from a

${ }^{3}$ Republic 436a-445e, 545b-580a
${ }^{4}$ Symposium 203b-209e

PLATO, The electronic Journal of the International Plato Society, 12, 2012.

http://gramata.univ-paris1.fr/Plato/article114.html,

(C) All rights of reproduction of any form reserved. 
purely ontological point of view, it is "hard" to imagine an intermediate position. However, from a psychological point of view, it looks right. Unfortunately, the author does not go deeply into the subject. Is it not true that the aim of Plato's philosophy is to find the "in-between" (metaxy)? A middle between the sensible and the intelligible? Does not the combined reading of the speech of Socrates/Diotima and Alcibiades underline the necessity of a union between human and divine? Presumably, Cooksey does not take any position on this subject because he regards the idea of Beauty as totally transcendental and ineffable, and this, therefore, leads him to perceive only the division, since he does not understand the intermediary role played by Eros from an ontological point of view.

4) The "ascent passage"s: as outlined in the previous paragraph, this passage regards the form of Beauty as not being limited by either the temporal or the spatial dimension, and seems to be also apart from the previous levels. The vision of the Beautiful would render all other measures of Beauty trivial: "Children, works of poetry, inventions, moral and political institutions are merely images or phantoms of virtues, mere approximations in their impure form, contingent on particular things." (p. 85). It seems to me, however, that Cooksey' interpretation does not account for the idea of the "big beautiful sea" - or at least, that was not its intention.

The author argues constantly about the secondary bibliography concerning three subjects: the ascent's doctrine regarding Plato's philosophy; the role of Diotima; and the relationship between the discourse of Socrates/Diotima with the five previous discourses. Cooksey [like Chen (1983)] does not interpret "the ascent" in terms of abstraction or generalization but as something comparable to the Zen Koans and capable of performing a similar function: the form of Beauty is beyond rational or empirical description. "We can only point at it; we do not have the means of saying what it is. Eros is a kind of orienting disposition." (p. 87). This marks a key point in the philosophical method proposed by Diotima. What I mean to say is that there is a discontinuity between the procedure and the grasp of Beauty, the vision of Beauty is neither insured nor guaranteed.

"This method can only prepare the lover/philosopher, put him in the proper place, the proper frame of mind, but it cannot by itself bridge the final gap." (p. 88). Cooksey understands it in a "kantianian" way, as the limits of reason, and conceives the grasp of Beauty as a mystical experience. The relationship between procedure and grasp is explained according to the words of Wittgenstein: "kicking away the ladder after we have climbed it." We already know that this passage has been read for centuries in two different and opposing ways: as an expression of rationality capable of abstraction and generalization, on the one hand, and as a mystical abandonment of the rationality, on the other. These two interpretations are rooted in some representations of Plato's gnoseology regarding the dianoia and the nous. Cooksey places himself among the supporters of a

${ }^{5}$ Symposium 209e-212a

PLATO, The electronic Journal of the International Plato Society, 12, 2012.

http://gramata.univ-paris1.fr/Plato/article114.html,

(C) All rights of reproduction of any form reserved. 
mystical interpretation and uses a method based on suggestions and assonances quoting and commenting passages of Dante, Shakespeare and George Bernard Shaw.

The figure of Diotima is presented as a strong presence that is absent: "Her presence as a name signifies something real about her existence, but at the same time something outside or beyond a material appearance of the others." (p. 94). According to Cooksey, Diotima's presence is a symbol of the entire process of immortality and the ascent that she describes. I think this is a highly interesting aspect because it frames, within the same characters' selection, a particular philosophical meaning: the philosophy of the ineffable beauty that remains absent in the presence of itself.

The author associates the erotic metaphor with the act of reading and interpretation. Each speech is stimulated to give birth to the beauty of knowledge and the ascent up of the ladder of love; and is dramatized by the succession of narrators and narrative frames. Cooksey offers an interpretation that could be called "maieutic". Furthermore, he shows how the narrative structure is represented by the philosophy stated by Socrates/Diotima: "(...) the nesting of narrative frames also reminds us that we are separated from Diotima's vision, that whatever we know about the beautiful is filtered by a succession of mediators." (pp. 95-96). It is only possible to grasp a phantom of Beauty, not Beauty itself.

5) Diotima and Alcibiades: while Diotima emphasizes the remote goals of the erotic, Alcibiades emphasizes its very tangible presence. Nevertheless, the erotic presence stated by Alcibiades underlines something that is placed outside the subjective control: an uncontrollable power.

I believe that Cooksey interprets love as a separation, even when it takes a corporeal appearance in Alcibiades' discourse. Cooksey - unlike Nussbaum (1986) -, argues that the idealized eroticism of Diotima is mapped onto the real eroticism of Alcibiades: his speech is not the "counter example" but the concrete example of Diotima's. According to Cooksey, the purpose of Plato - pursued by the discourse of Alcibiades - is to demonstrate that the metaphysical vision suggested by Diotima is to be present in everybody's daily life experience: "The steps in Alcibiades' account of his attempts to seduce Socrates echoes the stages of the erotic mysteries of Diotima, a concrete example of the five stages of love, especially the transitions between the stages." (p. 118).

6) Socratic philosophy: Cooksey places the desire for unattainable Beauty inside the Socratic philosophy as an enquiry. He thinks that Socrates offers a process, not a doctrine. "The erotic guide can facilitate and nurture, but it is the beloved who must experience the sudden revelation that takes the initiate to the fifth level (...)." (p. 123). Thus, he suggests a general interpretation that underlines the continuity between Socrates and Plato, which is to be found in the same writing, and is intended to encourage readers. He comes to this conclusion after considering the Socratic method as an endless tendency, a desire for an

PLATO, The electronic Journal of the International Plato Society, 12, 2012.

http://gramata.univ-paris1.fr/Plato/article114.html,

(C) All rights of reproduction of any form reserved. 
inaccessible wisdom and an absence of knowledge according to the interpretation of the "ascent passage" and that of Heidegger regarding Socrates as a "daimonic thinker." I not only do not agree, but consider that since it is possible to grasp the Idea, it should be investigated. But this would expose the whole interpretation of Cooksey as based on the separation, and therefore it is not taken into consideration.

The subject of separation has been widely debated in the secondary bibliography about Plato. Since this is a review, I cannot argue about it any longer. Nevertheless, I would like to state that as far as I'm concerned, from that specific point in the Symposium (i.e. the 'ascent passage') the interpretation of the alleged platonic 'dualism' could be called into question.

The author manages very cleverly to present a broad range of areas from ancient Greek philosophy to modern philosophy, but - probably because of the introductory nature of the text -; he doesn't go deeply into it. In this text, we find two strong points that deserve a specialist attention: the particular attention paid to the literary aspects of the dialogue - highlighting the philosophical meaning inherent to it - and the maieutic aspects that might lead to the understanding of the real aim of Plato's writing.

To conclude, I would say that the text of Cooksey is presented as a passionate and stimulating introduction to the Symposium. However, caution must be applied, as there is a high risk of misinterpretation for those readers who are not familiarized with platonic texts and the secondary literature. Yet it would be reduced if the text of Cooksey were supported by other studies. On the whole, the text of Cooksey is a refreshing interpretation rather than an introduction. Furthermore, it is packed with interesting suggestions and comparisons about the Symposium.

Laura CANDIOTTO

Ca' Foscari University of Venice (Italy)

Department of Philosophy

PLATO, The electronic Journal of the International Plato Society, 12, 2012.

http://gramata.univ-paris1.fr/Plato/article114.html,

(c) All rights of reproduction of any form reserved. 